\title{
Antibacterial activity of plant essential oils against indigenously characterized methicillin-resistant Staphylococcus aureus (MRSA)
}

\author{
Ali, T. ${ }^{1}$, Anjum, A.A. ${ }^{1 *}$, Sattar, M.M.K. ${ }^{2}$, Ali, M.A. ${ }^{1}$, Kamran, $M .{ }^{3}$, Tariq, $M .{ }^{1}$, Manzoor,.$^{1}$ \\ ${ }^{1}$ Institute of Microbiology, Faculty of Veterinary Science, University of Veterinary and Animal Sciences, Lahore, Pakistan (54000) \\ 2Department of Microbiology, Faculty of Veterinary and Animal Sciences, The Islamia University of Bahawalpur, Pakistan (63100) \\ ${ }^{3}$ Department of Parasitology \& Microbiology, Faculty of Veterinary and Animal Sciences, Pir Mehr Ali Shah Arid Agriculture University, Rawalpindi, \\ Pakistan (46000) \\ *Corresponding author: aftab.anjum@uvas.edu.pk
}

\section{ARTICLE HISTORY}

Received: 11 November 2021 Revised: 24 December 2021

Accepted: 24 December 2021 Published: 20 February 2022

\begin{abstract}
Plant essential oils were evaluated for antimicrobial activity against Methicillin-resistant Staphylococcus aureus (MRSA). The isolates $(n=03)$ were procured from Institute of Microbiology, UVAS Lahore, Pakistan. After biochemical and 16S rRNA gene-based PCR characterization, accession numbers were retrieved from NCBI i.e. MW344063.1, MW344064.1 and MW344065.1. These isolates exhibited molecular positivity by multiplex PCR for mecA, coa and eta toxin genes. Moreover, these isolates exhibited resistance to cefoxitin, ampicillin, amoxicillin, penicillin, amoxicillin clavulanate, ciprofloxacin, erythromycin and gentamicin. The antibiotic resistant isolates were evaluated for antimicrobial activity of plant essential oils. The highest zone of inhibition (mean ZOI \pm S.D.) was measured for Cinnamomum verum $(22.67 \pm 1.52$ $\mathrm{mm}$ ) followed by Eucalyptus globulus $(18.67 \pm 2.51 \mathrm{~mm})$ and Syzygium aromaticum $(12.67 \pm 2.51 \mathrm{~mm})$. Lowest mean MIC value $(0.33 \pm 0.11 \mathrm{mg} / \mathrm{mL})$ was recorded for $E$. globulus. Eucalyptus globulus was processed for fractionation by column chromatography and n-hexane, chloroform, n-hexane + chloroform and ethyl-acetate fractions were evaluated for antibacterial activity. Lowest mean MIC $(10.04 \pm 5.80 \mathrm{mg} / \mathrm{mL})$ was recorded for E. globulus $\mathrm{n}$-hexane fraction. Cell survival percentage of BHK21 cell line was $51.7 \%$ at $54.87 \mathrm{mg} / \mathrm{mL}$ concentration of E. globulus n-hexane fraction. Through gas chromatography-mass spectrometry (GC-MS) analysis of $n$-hexane fraction, benzene was found abundant $(29.9 \%)$ as active compound. It was concluded that $E$. globulus $\mathrm{n}$-hexane fraction exhibited significantly promising results against MRSA.
\end{abstract}

Keywords: Essential oil; Eucalyptus globules; methicillin resistance; n-hexane; Staphylococcus aureus.

\section{INTRODUCTIOIN}

Staphylococcus aureus is a gram positive bacterium having the diameter of $0.5-1.5 \mu \mathrm{m}$, non-motile and non-spore forming facultative anaerobe. The biochemical profile of $S$. aureus exhibits catalase-positive, oxidase-negative, coagulasepositive and it can tolerate high salt concentration and resistant to heat treatment (Vrbovská et al., 2020). Being natural inhabitant of skin microbiota, it usually causes nosocomial staphylococcal infections especially in immunocompromised individuals: septicemia, pyaemia, localized skin and other body infections. This ubiquitous bacterium is a significant pathogen due to combination patterns of toxinmediated virulence, antibiotic resistance and invasiveness (Kadariya et al., 2014).

Several strains of $S$. aureus produce enterotoxins A, B, C, $D$ and $E$ which can lead to food poisoning and also resistant to methicillin and $\beta$-lactams because of mecA gene that encodes penicillin binding protein PBP2a which are the specific characters of MRSA strains (Batista et al., 2013). Coagulase (coa) protein is a clotting factor secreted by MRSA that acts as virulence factor as well phenotypic determinant (Effendi et al., 2019). Multiplex PCR assay can be used for the detection of $\operatorname{mec} A$, coa and staphylococcus exfoliative toxin A (eta) genes (Bhowmik et al., 2021). It is a significant pathogen of public health concern because of increasing antibiotic resistance pattern. It shows a wide pattern of resistance against traditional antibiotics like macrolides, lincosamides, streptogramins (MLS), amino-glycosides, quinolones, $\beta$-lactams and glycopeptide groups and leads to emergence of multi-drug resistance (MDR) (Gurung et al., 2020).

Plant essential oils are being used as alternative therapeutics for the treatment of staphylococcal infections. Essentials oils (EOs) are the bioactive secondary metabolites of plants and also known as volatile oils. The EOs are extracted from vegetative parts (herbs, bark, leaves, wood and roots) and reproductive parts (flowers and fruits) of 
plants by different processes such as fermentation, extraction and steam distillation (Dorman \& Deans, 2000). The inhibitory effects of plant essential oils can be monitored by performing agar disc diffusion and broth microdilution methods such as minimum inhibitory concentration (MIC) against pathogenic S. aureus (LopezRomero et al., 2015).

Essential oil from the leaves of E. globulus is known as antioxidant and natural tonic. The chemical components of E. globulus oil can be analyzed by GC/MS which are oxygenated monoterpenes, 1, 8-cineole, spathulenol and $\alpha$-terpineol (Harkat-Madouri et al., 2015). The $C$. verum leaf EO shows antimicrobial activity against $S$. aureus due to major components such as cinnamaldehyde, eugenol, cinnamyl acetate, linalool, cinnamyl alcohol and p-cymene. The S. aromaticum EO is commonly known as clove oil and rich in phenolic compounds like eugenol, eugenol acetate and gallic acid as an effective antibacterial agent (Moemenbellah Fard et al., 2020). The active antimicrobial components of Ferula assa-foetida EO (hing oil) are propenyl sec-butyl disulfide, $\beta$-pinene, $\alpha$-pinene, thiophene and thiourea (Karimian et al., 2020).

This study was designed to identify the alternative therapeutic potential of various plant essential oils along with chemical component analysis by GC/MS of effective plant essential oil fractions against MRSA.

\section{MATERIALS AND METHODS}

\section{Revival of $S$. aureus isolates}

The $S$. aureus $(n=10)$ isolates were procured from Institute of Microbiology, University of Veterinary and Animal Sciences (UVAS), Lahore, Pakistan which were characterized on the basis of morphology and biochemical profile. The isolates stored on microbeads were revived on mannitol salt agar (MSA) at $37^{\circ} \mathrm{C}$ temperature for $24-48$ hours.

\section{Molecular Confirmation}

The DNA of S. aureus isolates was extracted through GeneAll ${ }^{\circledR}$ Exgene $^{\mathrm{TM}}$ DNA extraction kit by following the manufacturer recommendations. The $16 \mathrm{~S}$ rRNA gene based PCR was performed by using $\mathrm{n}=1$ pair of forward and reverse primers (Table 1). The PCR amplification was carried out in $25 \mu \mathrm{L}$ reaction mixture and $P C R$ reaction conditions were maintained as initial denaturation at $94^{\circ} \mathrm{C}$ for $10 \mathrm{~min}$ followed by 35 cycles of denaturation at $94^{\circ} \mathrm{C}$ for $1 \mathrm{~min}$, annealing at $55^{\circ} \mathrm{C}$ for $1 \mathrm{~min}$, extension at $72^{\circ} \mathrm{C}$ for $2 \mathrm{~min}$ and final extension at $72^{\circ} \mathrm{C}$ for $10 \mathrm{~min}$.

\section{Phylogenetic analysis}

The DNA amplicons were sequenced by using Sanger di-deoxy sequencing and retrieved in FASTA format. Sequences were cleaned by JUSTbio program then found the regions of high similarity using Basic Local Alignment Search Tool (BLAST-n) resulted in $97 \%$ to $98 \%$ homology between the sequences. These sequences also submitted to GenBank NCBI and accession numbers were obtained. A phylogenetic tree was constructed by picking the random sequences of $S$. aureus from GenBank NCBI along with sequenced data of 10 isolates of $S$. aureus using MEGA-X software.

\section{Antibiotic resistant, coagulase and toxin genes based Multiplex PCR}

Multiplex PCR amplification was based on mecA, coa and eta toxin using gene specific designed primers. A total of $25 \mu \mathrm{L}$ reaction mixture was used for each $\mathrm{PCR}$ reaction containing $12.5 \mu \mathrm{L}$ master mix, $8.5 \mu \mathrm{L}$ nuclease free water, $2 \mu \mathrm{L}$ of genomic DNA of each isolate and $1 \mu \mathrm{L}$ of $10 \mathrm{pmol} / \mu \mathrm{L}$ each mecA, coa and eta forward and reverse primers (Table 1). Amplification was done as initial denaturation at $94^{\circ} \mathrm{C}$ for 5 min followed by 35 cycles of denaturation at $94^{\circ} \mathrm{C}$ for $2 \mathrm{~min}$, annealing at $57^{\circ} \mathrm{C}$ for $2 \mathrm{~min}$, extension at $72^{\circ} \mathrm{C}$ for $1 \mathrm{~min}$ and final extension at $72^{\circ} \mathrm{C}$ for $7 \mathrm{~min}$. A DNA ladder of 100 to $1500 \mathrm{bp}$ was used and amplified products were separated on $1.8 \%$ agarose gel at voltage $5 \mathrm{~V} / \mathrm{cm}$ of gel length using $1 \mathrm{X}$ TAE tank buffer then observed under UV light for DNA bands visualization (Green \& Sambrook, 2021).

\section{Antibiotic sensitivity testing}

The $S$. aureus isolates $(n=3)$ confirmed by using mecA, coa and eta gene specific primers were analyzed for antibiotic susceptibility testing. By following clinical and laboratory standards institute (CLSI) 2020 manual, culture sensitivity testing was performed using Kirby-Bauer method for antibiotics such as amoxicillin, clavulanate, ampicillin, gentamicin, penicillin, ciprofloxacin, erythromycin, amoxicillin and cefoxitin. The inoculum of $S$. aureus cultures was prepared to 0.5 McFarland by adjusting the optical density to 0.1 at $630 \mathrm{~nm}$. The prepared inoculum cultures were swabbed on respective nutrient agar plates and dispensed antibiotic discs by disc dispenser. Plates were incubated at $37^{\circ} \mathrm{C}$ for 24 hours and after incubation, clear zone of inhibition was measured in millimeter by ruler. Zones of inhibition were marked as sensitive, resistant or intermediate by comparing with CLSI-2020 manual (Shahid et al., 2021).

\section{Antimicrobial activity of plant essential oils against $S$. aureus resistant isolates \\ Multiple antibiotic resistant isolates were further processed for antibacterial activity of commercially available plant essential oils $(n=4)$ including $S$. aromaticum, C. verum, $E$. globulus and $F$. assa-foetida. To check antimicrobial activity, well-diffusion method was used and $6 \mathrm{~mm}$ wells were cut using sterile well-borer. Nutrient agar plates were swabbed}

Table 1. Primer sequences used for molecular confirmation

\begin{tabular}{|c|c|c|c|c|}
\hline Gene & Primer name & Primers sequence & Amplicon bp & References \\
\hline \multirow[t]{2}{*}{$16 \mathrm{~S}$ rRNA } & $8 F L P-F$ & 5'-AGTTTGATCCTGGCTCAG-3' & 1500 & (Asghar et al., 2016) \\
\hline & XB4-R & 5'-GTGTGTACAAGGCCCGGGAAC-3' & & \\
\hline \multirow[t]{2}{*}{ Methicillin (mecA) } & MECA1-F1 & 5'-ACTGCTATCCACCCTCAAAC-3' & 163 & (Shahsavan et al., 2012) \\
\hline & MECA2-R & 5'-CTGGTGAAGTTGTAATCTGG-3' & & \\
\hline \multirow[t]{2}{*}{ Coagulase $(c o a)$} & COA1-F & 5'-CGAGACCAAGATTCAACAAG-3' & 970 & (Goh et al., 1992) \\
\hline & COA1-R & 5'-AAAGAAAAACCACTCACATCA-3' & & \\
\hline \multirow[t]{2}{*}{ Exfoliative toxin A (eta) } & ETA1-F & 5'-GCAGGTGTTGATTTAGCATT-3' & 93 & (Sila et al., 2009) \\
\hline & ETA2-R & 5'-AGATGTCCCTATTTTTGCTG-3' & & \\
\hline
\end{tabular}


by 24 hours incubated 0.5 MacFarland inoculum and oils with 1:1 ratio with dimethyl sulfoxide (DMSO) were poured in each well and the solvent also used as negative control. Culture plates were incubated at $37^{\circ} \mathrm{C}$ for $18-24$ hours and after incubation, the diameter of zones of inhibition around the wells were measured in millimeter by ruler (Malathy et al., 2021).

\section{Minimum Inhibitory Concentration (MIC) of plant essential oils} Minimum concentration of essential oil having ability to inhibit visible growth of $S$. aureus was evaluated by performing antimicrobial assay such as MIC. A volume of $100 \mu \mathrm{L}$ nutrient broth was pipetted in each row from $1^{\text {st }}$ to $12^{\text {th }}$ wells of 96 well flat bottom micro-titration plate. Two fold serial dilution of $100 \mu \mathrm{L}$ plant EO's such as S. aromaticum, C. verum, E. globulus and $F$. assa-foetida were made from $1^{\text {st }}$ to $10^{\text {th }}$ well each and $100 \mu \mathrm{L}$ volume was discarded from $10^{\text {th }}$ well. Bacterial suspension of $100 \mu \mathrm{L}(0.5 \mathrm{MacFarland})$ was pipetted from $1^{\text {st }}$ to $11^{\text {th }}$ wells each then optical density of micro-titration plate was taken at $630 \mathrm{~nm}$ at 0 time and 24 hours after the incubation at $37^{\circ} \mathrm{C}$. After this, the same MIC procedure was repeated for $E$. globulus fractions in n-hexane, chloroform, $\mathrm{n}$-hexane + chloroform and ethyl-acetate organic solvents (Argyri et al., 2021).

\section{Cytotoxicity analysis of plant essential oils}

Cytotoxicity assay of $E$. globulus oil $n$-hexane fraction was performed using Baby Hamster Kidney 21 (BHK-21) cell line which was grown in Glasgow minimum essential medium (GMEM) having 8-10\% Fetal Calf Serum (FCS). Using 96 wells flat bottom micro-titration plate, $1 \times 10^{5}$ BHK-21 cells were inoculated per $300 \mu \mathrm{L}$ GMEM in each well and after cell monolayer formation, 2 fold serial dilutions of $E$. globulus oil n-hexane fraction of essential oil were prepared followed by incubation at $37^{\circ} \mathrm{C}$ under $5 \% \mathrm{CO}_{2}$ concentration. After washing with sterile PBS, equal volume of $1 \%$ crystal violet solution and $3 \%$ formalin were used as staining solution and after washing stained cell line (96 well plate) was placed for overnight air drying. In each well, 50 $\mu$ L DMSO was added and optical density was taken at $570 \mathrm{~nm}$ by ELISA plate reader (Maurya et al., 2021). Using following formula, cell survival percentage was calculated as:

$$
\mathrm{CSP}=\frac{\text { Test O.D }- \text { Negative control O.D }}{\text { Live cell control O.D }- \text { Negative control O.D }} \times 100
$$

\section{GC/MS analysis of $E$. globulus oil}

E. globulus oil fraction in $\mathrm{n}$-hexane organic solvent was subjected for GC-MS analysis following the method of Azadmanesh and his fellows with minor modifications and for this, CARBOWAX capillary column along with helium as carrier gas was used. Sample injector was heated at $260^{\circ} \mathrm{C}$ and essential oil fraction made in 3 different solvents combinations were injected at $1 \mu \mathrm{L} /$ minute rate. Active compounds in tested sample were detected by comparison of retention time with standard compound (Azadmanesh et al., 2021).

\section{Statistical analysis}

Data obtained from antibiotic sensitivity, MIC and agar-well diffusion assay was analyzed through One way analysis of variance (ANOVA) followed by Duncan's multiple range test as post hoc by using Statistical package for social sciences (SPSS) Version 20.0 and level of significance ( $p$-value) of 0.05 was chosen for statistical analysis.

\section{RESULTS}

\section{Biochemical identification}

S. aureus isolates were identified as gram-positive cocci in clusters, positive for catalase, beta hemolysis and oxidase negative. Only 2 isolates were observed coagulase positive.

\section{Phylogenetic analysis}

S. aureus phylogenetic analysis (16S r RNA gene sequence) was performed through the Maximum Likelihood method, bootstrap consensus tree inferred from 1000 replicates by using 33 16S rRNA sequences from NCBI data base and 10 Pakistan S. aureus (colored star) sequences submitted to GenBank. Accession numbers were retrieved from NCBI i.e. MW344063.1, MW344064.1 and MW344065.1. S. aureus MW344064.1 and MW341439.1 are 98\% related to each other and both are $15 \%$ evolutionary related to MW344065.1 and MW341440.1, MW345972.1 35\% homologous to MW 344063.1 and MW341438.1 and both are $98 \%$ evolutionary related to each other (Figure 1).

Coagulase, methicillin and exfoliative toxin A gene amplification $S$. aureus isolates confirmed at molecular level $(n=03)$ were subjected to coa, mecA and eta gene amplification. Out of three, 2 isolates were observed positive for coagulase gene. All three isolates were positive for mecA gene and one isolate was observed positive for eta gene (Figure 2). As our 3 isolates were positive for mecA gene that clearly indicate towards MRSA.

\section{Antibiotic sensitivity}

Confirmed S. aureus isolates $(n=3)$ were subjected to antimicrobial susceptibility pattern and their zone of inhibitions were compared with clinical laboratory standard institute (CLSI). The highest mean zone of inhibition was recorded for amoxicillin clavulanate as mean ZOI \pm S.D. $(18.67 \pm 2.08 \mathrm{~mm})$ while lowest mean zone of inhibition was recorded for gentamicin $(1.67 \pm 2.88 \mathrm{~mm})$. As statistically, amoxicillin clavulanate antibiotic differ significantly $(p<0.05)$ from other group of antibiotics. The tested isolates were resistant to all the antibiotics as compared to CLSI-2020 standards (Table 2).

\section{Plant essential oils antimicrobial activity against $S$. aureus}

The antimicrobial pattern of selected plant essential oils were tested for $S$. aureus isolates with accession numbers MW344063.1, MW344064.1 and MW344065.1 by well diffusion method and zone of inhibitions were recorded. The highest zone of inhibition was measured for $C$. verum $\left(22.67 \pm 1.52^{c}\right.$ $\mathrm{mm}$ ) followed by $E$. globulus $\left(18.67 \pm 2.51^{\mathrm{b}} \mathrm{mm}\right)$, S. aromaticum $\left(12.67 \pm 2.51^{\mathrm{a}} \mathrm{mm}\right)$ and lowest for F. assa-foetida $\left(9.67 \pm 0.57^{\mathrm{a}} \mathrm{mm}\right)$ plant oil. Statistically, C. verum plant essential oil zone of inhibition differed significantly $(p<0.05)$ with other three plant essential oils and non-significance difference $(p>0.05)$ was observed among $S$. aromaticum and F. assa-foetida zones of inhibition.

Minimum inhibitory concentration (MIC) of plant essential oils was determined against $S$. aureus isolates. Mean MIC of E. globulus, C. verum, and F. assa-foetida differed non-significantly $(p>0.05)$ and $S$. aromaticum differed significantly $(p<0.05)$ from other plant essential oils. Lowest mean MIC was recorded for E. globulus $\left(0.33 \pm 0.11^{\mathrm{a}} \mathrm{mg} / \mathrm{mL}\right)$ and highest mean MIC was observed against $S$. aromaticum $\left(10.03 \pm 3.47^{\mathrm{b}} \mathrm{mg} / \mathrm{mL}\right.$ ) essential oil (Table 3$)$. 


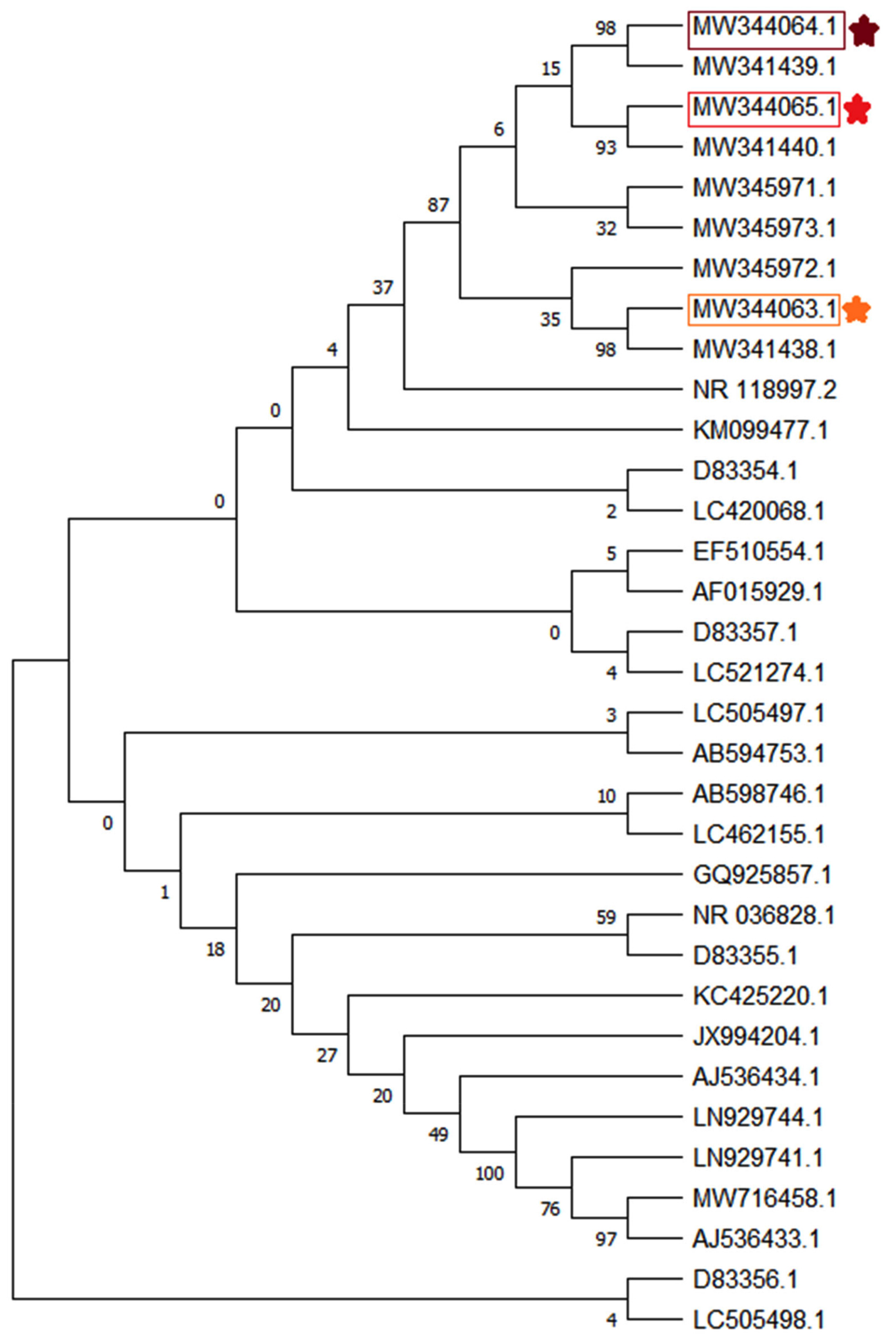

Figure 1. Phylogenetic analysis based on 16S rRNA gene sequences of $S$. aureus. 


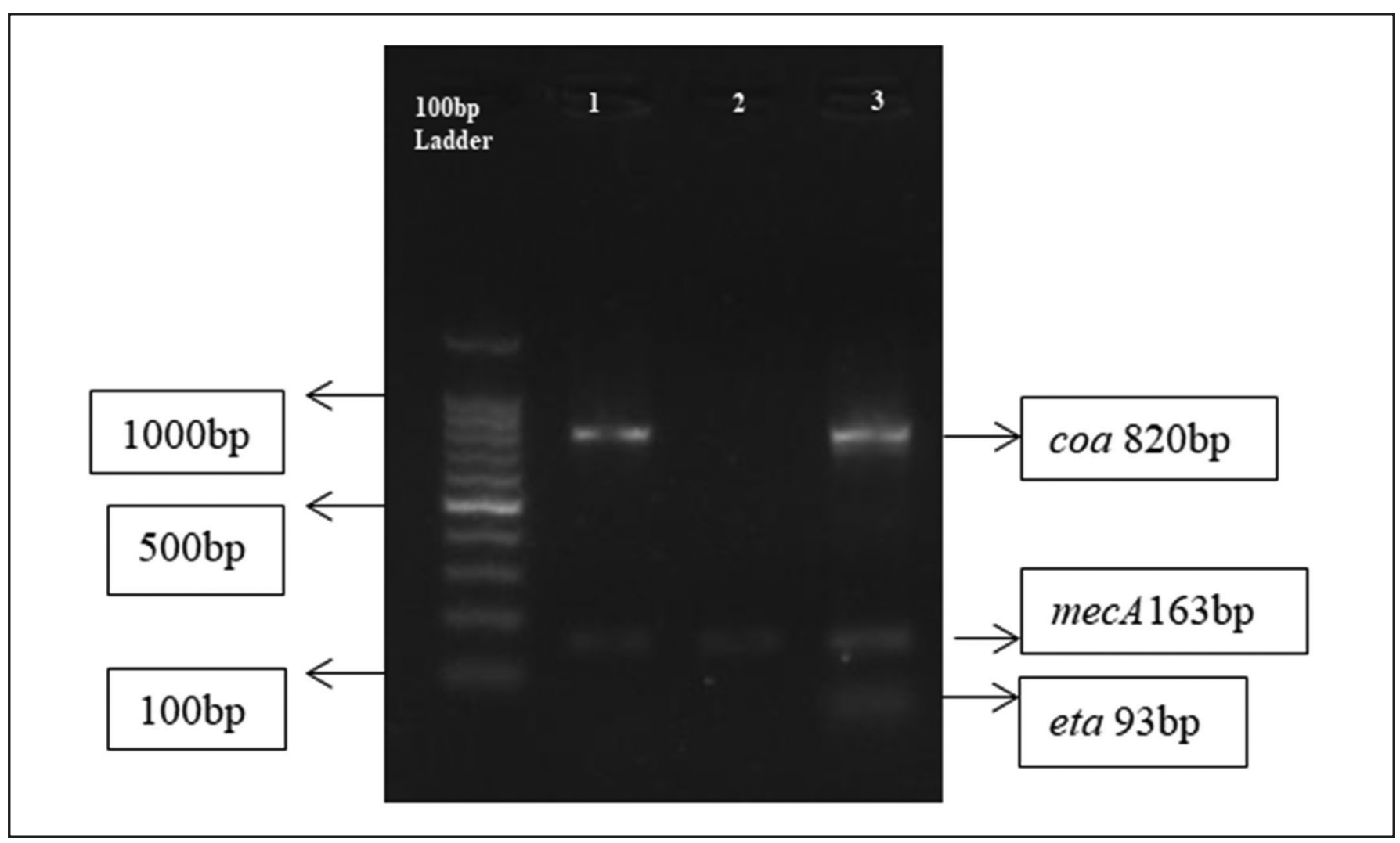

Figure 2. Methicillin resistant, coagulase and exfoliative toxin genes based Multiplex PCR. Lanes 1, 2 and 3: multiplex PCR product of Methicillin resistant Staphylococcus aureus isolates 1, 2 and 3.

Table 2. Antibiotic sensitivity of $S$. aureus isolates

\begin{tabular}{|c|c|c|c|c|c|c|}
\hline \multirow{2}{*}{ Sr. No } & \multirow{2}{*}{ Antibiotics } & \multirow{2}{*}{ Conc. ( $\mu \mathrm{g})$} & \multicolumn{3}{|c|}{ CLSI Standards (mm) } & \multirow{2}{*}{ Mean ZOI \pm S.D. } \\
\hline & & & Resistant & Intermediate & Sensitive & \\
\hline 1 & Cefoxitin & 30 & $R \leq 21$ & - & $S \geq 22$ & $12.00 \pm 2.00^{c, d}$ \\
\hline 2 & Ampicillin & 10 & $R \leq 21$ & - & $S \geq 22$ & $12.67 \pm 3.05^{c, d}$ \\
\hline 3 & Amoxicillin & 25 & $R \leq 21$ & - & $S \geq 22$ & $11.33 \pm 1.52^{\mathrm{c}, \mathrm{d}}$ \\
\hline 4 & Penicillin & 10 & $R \leq 28$ & - & $S \geq 29$ & $13.33 \pm 0.57^{c, d, e}$ \\
\hline 5 & Augmentin & 30 & $R \leq 21$ & - & $S \geq 22$ & $18.67 \pm 2.08^{\mathrm{d}, \mathrm{e}}$ \\
\hline 6 & Ciprofloxacin & 5 & $R \leq 15$ & $\mathrm{I}=16-20$ & $S \geq 21$ & $9.67 \pm 1.15^{b, c}$ \\
\hline 7 & Erythromycin & 15 & $R \leq 13$ & $\mathrm{I}=14-22$ & $S \geq 23$ & $3.33 \pm 5.77^{a, b}$ \\
\hline 8 & Gentamycin & 10 & $\mathrm{R} \leq 12$ & $\mathrm{I}=13-14$ & $S \geq 15$ & $1.67 \pm 2.88^{\mathrm{a}}$ \\
\hline
\end{tabular}

Value with different superscripts $(a, b, c, d, e)$ differ significantly $(p<0.05)$, with similar differ non-significantly $(p>0.05)$ and vice versa.

Table 3. MIC of plant essential oils against MRSA

\begin{tabular}{llcccc}
\hline $\begin{array}{l}\text { Sr. } \\
\text { No }\end{array}$ & Plant Essential oils & \multicolumn{3}{c}{$\begin{array}{c}\text { MIC Values } \\
(\mathrm{mg} / \mathrm{ml})\end{array}$} & $\begin{array}{c}\text { Mean MIC } \\
\pm S . D .\end{array}$ \\
\hline 1 & Syzygium aromaticum & 12.04 & 12.04 & 6.02 & $\begin{array}{c}10.03 \pm 3.47^{\mathrm{b}} \\
2\end{array}$ \\
Eucalyptus globulus & 0.40 & 0.20 & 0.40 & $0.33 \pm 0.11^{\mathrm{a}}$ \\
3 & Cinnamomum verum & 0.41 & 0.41 & 0.82 & $0.54 \pm 0.23^{\mathrm{a}}$ \\
4 & Ferula assa-foetida & 6.29 & 0.78 & 0.78 & $2.61 \pm 3.18^{\mathrm{a}}$ \\
\hline
\end{tabular}

Antimicrobial activity of Eucalyptus globulus essential oil fractions As E. globulus plant essential oil exhibited lowest MIC value and was further subjected for fractionation by column chromatography to study the effective antimicrobial pattern. Four fractions of E. globulus such as n-hexane, chloroform, n-hexane + chloroform and ethyl-acetate were obtained. Lowest mean MIC was recorded for $n$-hexane fraction $(10.04 \pm 5.80 \mathrm{mg} / \mathrm{mL})$ and highest mean MIC was recorded for chloroform fraction $(83.83 \pm 36.30 \mathrm{mg} / \mathrm{mL})$. Statistically, mean MIC of $n$-hexane fraction differs significantly with other three fractions and chloroform, n-hexane + chloroform and ethylacetate differ non-significantly with each other.

\section{Cytotoxicity of $n$-hexane fraction of $E$. globulus essential oil}

The lowest MIC was recorded for E. globulus n-hexane fraction as compared to chloroform, n-hexane + chloroform and ethyl acetate fractions. E. globulus n-hexane fraction was processed for cytotoxicity assay. Cytotoxicity was evaluated on BHK21 cell line and cell survival percentage was $51.7 \%$ at $54.87 \mathrm{mg} /$ $\mathrm{mL}$ concentration and this concentration relates to the exact MIC concentration exhibited by oil fraction. 
Table 4. GCMS analysis of E. globulus n-hexane fraction

\begin{tabular}{lcc}
\hline Compounds & Retention time & Percentages \\
\hline Bicyclo[4.1.0]heptane & 14.4 & 0.33 \\
Benzene & 15.1 & 1.9 \\
Benzene & 15.3 & 29.9 \\
Cyclohexano & 15.4 & 3.8 \\
$\gamma$-Terpinene & 16 & 2.55 \\
Cyclohexene & 16.5 & 5.22 \\
Benzene & 16.6 & 3 \\
Trans-4-methoxy thujane & 18.1 \\
Anisole, 2-isopropyl-5-methyl & 18.5 \\
Bicyclo[3.1.0]hexane, 6-isopropylidene-1-methyl & 19.1 \\
3-Cyclohexene-1-methanol, $\alpha, \alpha, 4-$ trimethyl-, acetate & 19.2 \\
2,4-Octadienoic acid, 3-methyl & 20.7 \\
Octane & 21.2 & 3 \\
Methoxycitronellal & 22 & 3.8 \\
Longifolene & 22.8 & 0.5 \\
\hline
\end{tabular}

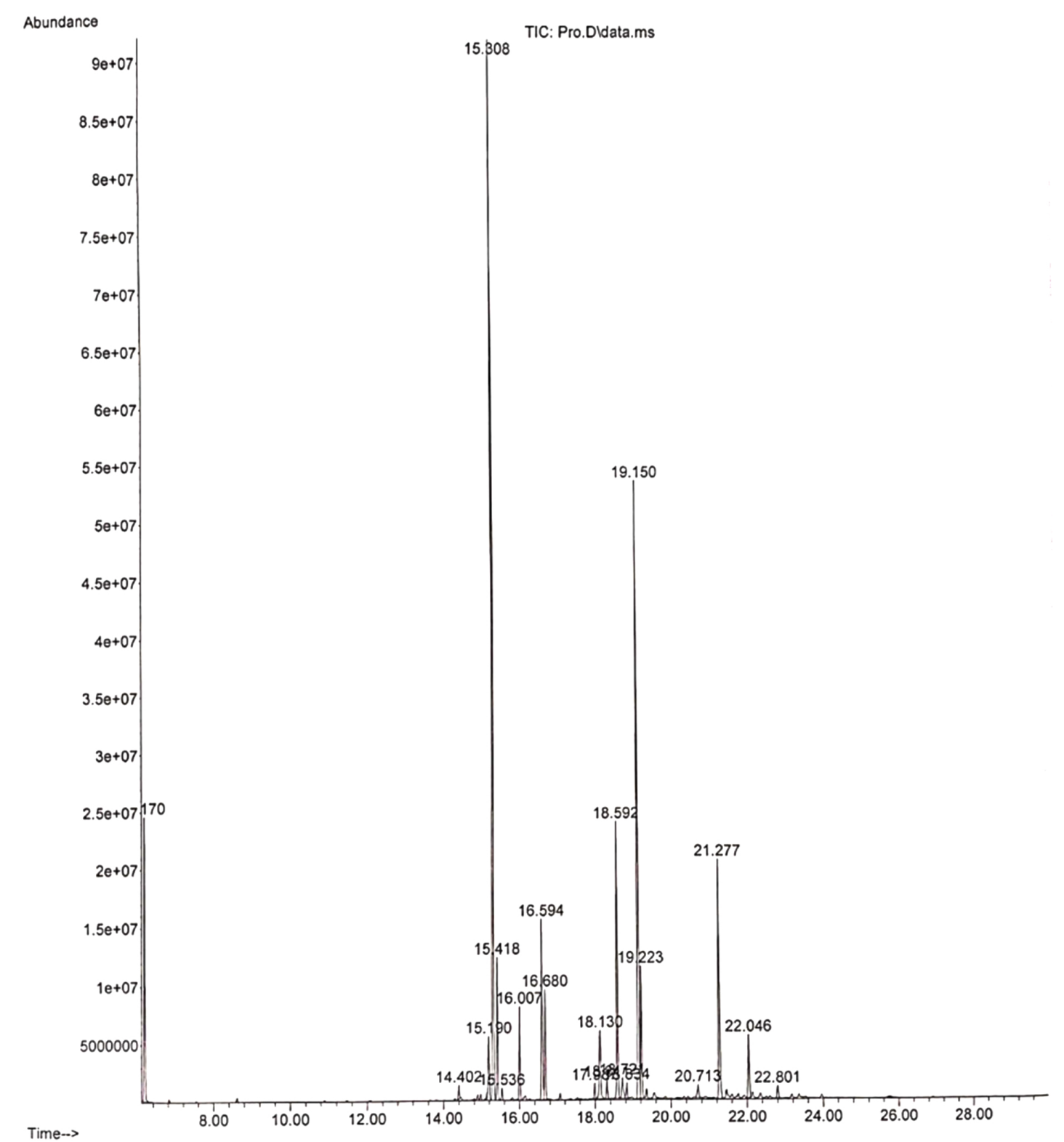

Figure 3. Chromatogram of E. globulus oil $\mathrm{n}$-hexane fraction by GC-MS analysis. 


\section{GC-MS analysis}

Through GC-MS analysis in n-hexane fraction of E. globulus essential oil, benzene was found $29.9 \%$ abundant as active compound. Bicyclo [3.1.0] hexane, 6-isopropylidene-1-methyl in n-hexane fraction of $E$. globulus was found second abundant (17.7\%) active compound (Table 4, Figure 3).

\section{DISCUSSION}

Clinical and diagnostic laboratories mostly use manual, automated phenotypic and commercial bacterial identification methods (Church et al., 2020). Gram staining, colony characters, growth requirements, metabolic and enzymatic reactions fall into phenotypic methods of identification, but these methods have been altered due to environmental stress and evolution (Ochman et al., 2005). Identification through biochemical test results can be compromised by inexperience and technologist's bias. Ribosomal RNA 16S gene sequence based genotypic identification has emerged as an accurate, objective and reliable method for bacterial identification with defining taxonomic relationships among bacteria (Alown et al., 2021). Our results were in agreement to the findings of Krimmer and his co-workers that $16 \mathrm{~S}$ rRNA gene sequencing is quite efficient and economic method than whole gene sequencing for bacterial species confirmation at molecular level (Krimmer et al., 1999).

The MRSA, one type of nosocomial pathogen is spreading probably due to continues overuse of broad spectrum beta lactam antibiotics (Fatholahzadeh et al., 2009). The MRSA was identified through methicillin resistant gene amplification. In present study, characterized isolates $(n=3)$ were positive for containing resistance genes. Present study results were in agreement to Algammal et al. (2020). Coagulase enzyme is main virulence factor of $S$. aureus leads to the clotting of plasma in host. It causes conversion of fibrinogen to fibrin and fibrin production shields the bacteria from phagocytosis. In laboratory, coagulase test has been done as standard phenotypic test and researchers implement the coagulase gene identification test as accurate defined test. Coagulase is highly polymorphic because it contains palindromic sequences (variable region based on length) at $3^{\prime}$ end ( $81 \mathrm{bp}$ tandem repeat) (AL-Zengena et al., 2019). Due to these sequences, difference in amplified products was observed when amplification was performed using same primer sets (Schwarzkopf, 1995). But in present study by using same primer set, amplicons with similar band size were obtained after amplification and 2 out of 3 isolates were positive for coagulase (coa) gene. These results were in contrast to study of Javed and his colleagues (Javid et al., 2018). Exfoliative toxin (ET) of S. aureus is responsible for causing blisters in bullous impetigo and in disseminated form as staphylococcal scaled skin syndrome (SSSS) (Lange et al., 2020). ET has 3 iso-forms such as ETA, ETB and ETD. In the present study, only one isolate was observed positive for ETA (eta) gene among $3 \mathrm{~S}$. aureus isolates.

The $S$. aureus infections especially MRSA is difficult to treat due to resistant to various antibiotics (Algammal et al., 2020). According to CLSI-2020 manual, level of bacterial resistance is grouped in to sensitive, intermediate and resistance. Cefoxitin, ampicillin, amoxicillin, pencillin and amoxicillin clavulanate fall in beta lactam antibiotic group and $S$. aureus exhibited resistance to beta lactam antibiotics. Previously similar pattern was observed by Tyasningsih and his co-workers (Tyasningsih et al., 2019). As, these antibiotics disrupt the cell wall synthesis (peptidoglycan). Bacteria produced beta lactamase which break up the beta lactam ring so beta lactam antibiotic become unable to bind to penicillin binding proteins (PBPs) (Effendi, 2009).
Essential oils are extensively used in pharmaceuticals, cosmetics and in beverage industry and known as natural plant products. Herbs chemical extracts and oils are used as medicine to treat various bacterial infections. The reason behind their usage is emerging bacterial resistance to commercial synthetic antibiotics. Clove oil exhibits antimicrobial activity against $S$. aureus, $K$. pneumonia, E. coli and E. faecium (Weber et al., 2004). In this study, F. assa-foetida EO inhibited S. aureus at $2.61 \pm 3.18 \mathrm{mg} / \mathrm{mL}$ concentration while Sharopov and coworkers found that $F$. assa-foetida EO in $0.5-4 \mu \mathrm{L} / \mathrm{mL}$ concentration inhibited $S$. aureus growth (Sharopov et al., 2019). The $C$. verum EO exhibited zone of inhibition against $S$. aureus growth with $22.67 \pm 1.52 \mathrm{~mm}$ and $0.54 \pm 0.23 \mathrm{mg} / \mathrm{mL}$ MIC value was recorded. The antibacterial activity of $C$. verum oil is due to the active component cinnamaldehyde (Wijesinghe et al., 2021). The E. globulus EO exhibits prominent antibacterial activity against gram positive microorganisms including $S$. aureus. E. globulus EO showed second highest inhibition zone against $S$. aureus isolates. Among solvent fractions of E. globulus, n-hexane fraction proved promising against $S$. aureus. Present study results were in agreement to results of Pereira and his colleagues (Pereira et al., 2014) and Ali and his coworkers (Ali et al., 2021).

Essential oils are used for the therapy of various microbial infections and for this purpose, their in-vitro and in-vivo evaluation is mandatory. Cytotoxicity assays are performed for this purpose on several types of eukaryotic cell lines. It was concluded that cytopathic effects of essential oils are dependent on concentration; higher the concentration higher will be the cytotoxicity. E. globulus cytotoxicity was ascertained by brine shrimp lethality test (BSLT) (Akolade et al., 2012) and results were observed in agreement to Falah and his colleagues (Falah et al., 2021) that when concentration was increased, increase in cytotoxic effect was observed. For cytotoxicity testing of E. globulus oils, MIC concentration was used. In this present study, cell survival increased (92-98\%) with the decrease of oil concentration $(1.85-1.89 \mathrm{mg} / \mathrm{mL})$.

The GC-MS is gold standard test for chemical composition analysis of different organic and inorganic compounds, extracts, oils and nanoparticles (Behbahani et al., 2019). Eucalyptus plant essential oils are used as folk medicines as anti-inflammatory, analgesic and antipyretic tonics. E. globulus fresh leave essential oil was analyzed through GC/MS and twenty components were identified. The highest percentage of 48.6 was recorded for 1,8 -cineole as active component (Daroui-Mokaddem et al., 2010). Nearly 45 components from $E$. globulus fruit oil were identified through GLC/MS. Aromadendrene has been found in abundance (31.17\%) followed by 1,8 -cineole $14.55 \%$ and globulol $10.69 \%$ (Mulyaningsih et al., 2010). Mulyaningsih and his collegues have founded 1,8 -cineole as second abundant active component in essential oil that is in contrast to DarouiMokaddem and his co-workers findings. Compound 1,8cineole was found $77.02 \%$ in essential oil as $1^{\text {st }}$ active chemical in agreement to Daroui-Mokaddem and his collegues study (Daroui-Mokaddem et al., 2010). In present study, E. globulus essential oil n-hexane fraction was subjected to GC/MS analysis and benzene was found $29.9 \%$ abundant as compared to other components as active compound followed by Bicyclo [3.1.0] hexane, 6isopropylidene-1-methyl $17.7 \%$ as $2^{\text {nd }}$ active component in essential oil fraction. As cytotoxicity test was performed to evaluate the safety index of $n$-hexane oil fraction so benzene can be considered safe if used within reported concentration. These findings were in contrast to the previous studies (Thappa et al., 1990). 
E. globulus essential oil and its n-hexane fraction are better alternate for treatment in antibiotic resistant cases of MRSA (Takahashi et al., 2004). Due to less cytotoxicity, this oil can be the alternative therapeutic option for the treatment of MRSA infections via oral route or transdermal application.

\section{Conflict of interest}

The authors declare that they have no conflict of interests.

\section{REFERENCES}

Akolade, J.O., Olajide, O.O., Afolayan, M.O., Akande, S.A., Idowu, D.I. \& Orishadipe, A.T. (2012). Chemical composition, antioxidant and cytotoxic effects of Eucalyptus globulus grown in north-central Nigeria. Journal of Natural Product and Plant Resources 2: 1-8.

AL-Zengena, I.A., Al-Taai, H.R. \& Al-Dulaimi, A.A. (2019). Molecular and genetics analysis of coagulase (coa) gene polymorphism in clinical isolates of Staphylococcus aureus by pcr-rflp in patient of baquba city, iraq. Biochemical and Cellular Archives 20: 1513-1517. https://doi.org/10.35124/ bca.2020.20.1.1513

Algammal, A.M., Hetta, H.F., Elkelish, A., Alkhalifah, D.H.H., Hozzein, W.N., Batiha, G.E-S., El-Nahhas, N. \& Mabrok, M.A. (2020). Methicillin-Resistant Staphylococcus aureus (MRSA): One health perspective approach to the bacterium epidemiology, virulence factors, antibiotic-resistance, and zoonotic impact. Infection and Drug Resistance 13: 32553265. https://doi.org/10.2147/IDR.S272733

Ali, M., Avais, M., Jamal, M.A., Ijaz, M., Chaudhry, M., Aqib, A.I., Khan, M.A., Ahmed, M., Hasni, M.S., Hameed, S. et al. (2021). Combating multidrug-resistant Staphylococcus aureus isolated from camel milk with extracts of Eucalyptus globulus and Calotropis procera, and their potential role in modulation of resistance to beta-lactam drugs. Medycyna Weterynaryjna-Veterinary Medicine-Science and Practice 77: 491-496. https://doi.org/10.21521/mw.6583

Alown, F., Alsharidah, A. \& Shamsah, S. (2021). Genotypic characterization of soil bacteria in the Umm Al-Namil Island, Kuwait. Saudi Journal of Biological Sciences. https:// doi.org/10.1016/j.sjbs.2021.03.060

Argyri, A.A., Doulgeraki, A.I., Varla, E.G., Bikouli, V.C., Natskoulis, P.I., Haroutounian, S.A., Moulas, G.A., Tassou, C.C. \& Chorianopoulos, N.G. (2021). Evaluation of plant origin essential oils as herbal biocides for the protection of caves belonging to natural and cultural heritage sites. Microorganisms 9: 1836. https://doi.org/10.3390/micro organisms9091836

Azadmanesh, R., Tatari, M., Asgharzade, A., Taghizadeh, S.F. \& Shakeri, A. (2021). GC/MS profiling and biological traits of Eucalyptus globulus L. essential oil exposed to Solid Lipid Nanoparticle (SLN). Journal of Essential Oil Bearing Plants 24: 863-878. https://doi.org/10.1080/0972060X.2021. 1973912

Batista, J.E.C., Ferreira, E.L., Nascimento, D.C.O., Ventura, R.F., de-Oliveira, W.L.M., Leal, N.C. \& Lima-Filho, J.V. (2013). Antimicrobial resistance and detection of the mec $A$ Gene besides enterotoxin-encoding genes among coagulasenegative Staphylococci isolated from clam meat of Anomalocardia brasiliana. Foodborne Pathogens and Disease 10: 1044-1049. https://doi.org/10.1089/fpd.2013.1576

Behbahani, B.A., Noshad, M. \& Falah, F. (2019). Study of chemical structure, antimicrobial, cytotoxic and mechanism of action of Syzygium aromaticum essential oil on foodborne pathogens. Potravinarstvo Slovak Journal of Food Sciences 13: 875-883. https://doi.org/10.5219/1226
Bhowmik, D., Chetri, S., Das, B.J., Chanda, D.D. \& Bhattacharjee, A. (2021). Distribution of virulence genes and SCCmec types among methicillin-resistant Staphylococcus aureus of clinical and environmental origin: a study from community of Assam, India. BMC Research Notes 14: 58. https://doi.org/10.1186/s13104-021-05473-3

Church, D.L., Cerutti, L., Gürtler, A., Griener, T., Zelazny, A. \& Emler, S. (2020). Performance and application of $16 \mathrm{~S}$ rRNA gene cycle sequencing for routine identification of bacteria in the clinical microbiology laboratory. Clinical Microbiology Reviews 33: e00053-19. https://doi.org/10.1128/ CMR.00053-19

Daroui-Mokaddem, H., Kabouche, A., Bouacha, M., Soumati, B., El-Azzouny, A., Bruneau, C. \& Kabouche, Z. (2010). GC/ MS analysis and antimicrobial activity of the essential oil of fresh leaves of Eucalytus globulus, and leaves and stems of Smyrnium olusatrum from Constantine (Algeria). Natural Product Communications 5: 1669-1672. https:// doi.org/10.1177/1934578X1000501031

Dorman, H.J.D. \& Deans, S.G. (2000). Antimicrobial agents from plants: antibacterial activity of plant volatile oils. Journal of Applied Microbiology 88: 308-316. https://doi.org/ 10.1046/j.1365-2672.2000.00969.x

Effendi, M.H. (2009). Peta Resistensi Antibiotika Staphylococcus aureus dari Kasus Mastitis Sapi Perah di Beberapa Daerah Peternakan. Media Kedokteran Hewan 24: 159-164.

Effendi, M.H., Hisyam, M.A.M., Hastutiek, P. \& Tyasningsih, W. (2019). Detection of coagulase gene in Staphylococcus aureus from several dairy farms in East Java, Indonesia, by polymerase chain reaction. Veterinary World 12: 68-71. https://doi.org/10.14202/vetworld.2019.68-71

Falah, F., Shirani, K., Vasiee, A., Yazdi, F.T. \& Behbahani, B.A. (2021). In vitro screening of phytochemicals, antioxidant, antimicrobial, and cytotoxic activity of Echinops setifer extract. Biocatalysis and Agricultural Biotechnology 35: 102102. https://doi.org/10.1016/j.bcab.2021.102102

Fatholahzadeh, B., Emaneini, M., Aligholi, M., Gilbert, G., Taherikalani, M., Jonaidi, N., Eslampour, M.A. \& Feizabadi, M.M. (2009). Molecular characterization of methicillinresistant Staphylococcus aureus clones from a teaching hospital in Tehran. Japan Journal of Infectious Diseases 62: 309-311.

Goh, S-H., Byrne, S., Zhang, J. \& Chow, A. (1992). Molecular typing of Staphylococcus aureus on the basis of coagulase gene polymorphisms. Journal of Clinical Microbiology 30: 1642-1645. https://doi.org/10.1128/jcm.30.7.1642-1645.1992

Green, M.R. \& Sambrook, J. (2021). Separation of RNA according to size: Electrophoresis of RNA through denaturing urea polyacrylamide gels. Cold Spring Harbor Protocols 2021: pdb. prot101766. https://doi.org/10.1101/pdb.prot101766

Gurung, R.R., Maharjan, P. \& Chhetri, G.G. (2020). Antibiotic resistance pattern of Staphylococcus aureus with reference to MRSA isolates from pediatric patients. Future Science OA 6: FSO464. https://doi.org/10.2144/fsoa-2019-0122

Harkat-Madouri, L., Asma, B., Madani, K., Said, Z.B-O.S., Rigou, P., Grenier, D., Allalou, H., Remini, H., Adjaoud, A. \& Boulekbache-Makhlouf, L. (2015). Chemical composition, antibacterial and antioxidant activities of essential oil of Eucalyptus globulus from Algeria. Industrial Crops and Products 78: 148-153. https://doi.org/10.1016/j.indcrop. 2015.10.015

Javid, F., Taku, A., Bhat, M.A., Badroo, G.A., Mudasir, M. \& Sofi, T.A. (2018). Molecular typing of Staphylococcus aureus based on coagulase gene. Veterinary World 11: 423-430. https:// doi.org/10.14202/vetworld.2018.423-430

Kadariya, J., Smith, T.C. \& Thapaliya, D. (2014). Staphylococcus aureus and staphylococcal food-borne disease: an ongoing 
challenge in public health. BioMed Research International 2014: 827965. https://doi.org/10.1155/2014/827965

Karimian, V., Sepehry, A., Barani, H., Ebrahimi, S.N. \& Mirjalili, M.H. (2020). Productivity, essential oil variability and antioxidant activity of Ferula assa-foetida L. oleo-gum-resin during the plant exploitation period. Journal of Essential Oil Research 32: 545-555. https://doi.org/10.1080/10412905. 2020.1794988

Krimmer, V., Merkert, H., von-Eiff, C., Frosch, M., Eulert, J., Lohr, J.F., Hacker, J. \& Ziebuhr, W. (1999). Detection of Staphylococcus aureus and Staphylococcus epidermidis in clinical samples by $16 \mathrm{~S}$ rRNA-directed in situ hybridization. Journal of Clinical Microbiology 37: 2667-2673. https://doi.og/ 10.1128/JCM.37.8.2667-2673.1999

Lange, J., Heidenreich, K., Higelin, K., Dyck, K., Marx, V., Reichel, C., Wamel, W., Reijer, M., Görlich, D. \& Kahl, B.C. (2020). Staphylococcus aureus pathogenicity in cystic fibrosis patients - results from an observational prospective multicenter study concerning virulence genes, phylogeny, and gene plasticity. Toxins 12: 279. https://doi.org/10.3390/ toxins 12050279

Lopez-Romero, J.C., González-Ríos, H., Borges, A. \& Simões, M. (2015). Antibacterial effects and mode of action of selected essential oils components against Escherichia coli and Staphylococcus aureus. Evidence-Based Complementary and Alternative Medicine 2015: 795435. https://doi.org/ 10.1155/2015/795435

Malathy, B., Sweetlin-Ajitha, P., Sangeetha, K.S., Thampy, S. \& Kamala, G. (2021). Antimicrobial activity of Commercial essential oils on human pathogens. Research Journal of Pharmacy and Technology 14: 4440-4444. http://doi.org/ 10.52711/0974-360X.2021.00771

Maurya, A.K., Sharma, A., Kumar, K., Chander, R., Kumar, A., Kumar, D., Padwad, Y.S., Chand, G. \& Agnihotri, V.K. (2021). Comparative studies of essential oils composition and cytotoxic activity of Valeriana jatamansi Jones. Journal of Essential Oil Research 33: 584-591. https://doi.org/10.1080/ 10412905.2021.1966846

Moemenbellah Fard, M.D., Abdollahi, A., Ghanbariasad, A. \& Osanloo, M. (2020). Antibacterial and leishmanicidal activities of Syzygium aromaticum essential oil versus its major ingredient, eugenol. Flavour and Fragrance Journal 35: 534-540. https://doi.org/10.1002/ffj.3595

Mulyaningsih, S., Sporer, F., Zimmermann, S., Reichling, J. \& Wink, M. (2010). Synergistic properties of the terpenoids aromadendrene and 1,8-cineole from the essential oil of Eucalyptus globulus against antibiotic-susceptible and antibiotic-resistant pathogens. Phytomedicine 17: 10611066. https://doi.org/10.1016/j.phymed.2010.06.018

Ochman, H., Lerat, E. \& Daubin, V. (2005). Examining bacterial species under the specter of gene transfer and exchange. Proceedings of the National Academy of Sciences 102: 65956599. https://doi.org/10.1073/pnas.0502035102

Pereira, V., Dias, C., Vasconcelos, M.C., Rosa, E. \& Saavedra, M.J. (2014). Antibacterial activity and synergistic effects between Eucalyptus globulus leaf residues (essential oils and extracts) and antibiotics against several isolates of respiratory tract infections (Pseudomonas aeruginosa). Industrial Crops and Products 52: 1-7. https://doi.org/10.1016/ j.indcrop.2013.09.032

Schwarzkopf, A. (1995). Coagulase gene polymorphism in Staphylococcus aureus - a new epidemiologic marker. Immunitat und Infektion 23: 9-14.

Shahid, A.H., Nazir, K.N.H., El-Zowalaty, M.E., Kabir, A., Sarker, S.A., Siddique, M.P. \& Ashour, H.M. (2021). Molecular detection of vancomycin and methicillin resistance in
Staphylococcus aureus isolated from food processing environments. One Health 13: 100276. https://doi.org/ 10.1016/j.onehlt.2021.100276

Shahsavan, S., Emaneini, M., Khoshgnab, B.N., Khoramian, B., Asadollahi, P., Aligholi, M., Jabalameli, F., Eslampour, M.A. \& Taherikalani, M. (2012). A high prevalence of mupirocin and macrolide resistance determinant among Staphylococcus aureus strains isolated from burnt patients. Burns 38: 378-382. https://doi.org/10.1016/j.burns.2011.09.004

Sharopov, F.S., Khalifaev, P.D., Satyal, P., Sun, Y., Safomuddin, A., Musozoda, S., Wink, M. \& Setzer, W.N. (2019). The chemical composition and biological activity of the essential oil from the underground parts of Ferula tadshikorum (Apiaceae). Records of Natural Products 13: 1823. https://doi.org/10.25135/mp.65.18.02.089

Sila, J., Sauer, P. \& Kolar, M. (2009). Comparison of the prevalence of genes coding for enterotoxins, exfoliatins, panton-valentine leukocidin and tsst-1 between methicillin-resistant and methicillin-susceptible isolates of Staphylococcus aureus at the university hospital in olomouc. Biomedical Papers of the Medical Faculty of the University of Palacky, Olomouc, Czechoslovakia Republic 153: 215-218.

Takahashi, T., Kokubo, R. \& Sakaino, M. (2004). Antimicrobial activities of eucalyptus leaf extracts and flavonoids from Eucalyptus maculata. Letters in Applied Microbiology 39: 6064. https://doi.org/10.1111/j.1472-765X.2004.01538.x

Thappa, R.K., Agarwal, S.G., Kalia, N.K. \& Kapoor, R.K. (1990). Essential oils from exotic eucalyptus: Leaf oils of Eucalyptus youmonii, Eucalyptus macrorhyncha, Eucalyptus macarthuri, and Eucalyptus cinera from northwest Himalays (India). Journal of Wood Chemistry and Technology 10: 543549. https://doi.org/10.1080/02773819008050256

Tyasningsih, W., Effendi, M.H., Budiarto, B. \& Syahputra, I.R. (2019). Antibiotic resistance to Staphylococcus aureus and methicillin resistant Staphylococcus aureus (MRSA) isolated from dairy farms in Surabaya, Indonesia. The Indian Veterinary Journal 96: 27-31.

Vrbovská, V., Sedláček, I., Zeman, M., Švec, P., Kovařovic, V., Šedo, O., Laichmanová, M., Doškař, J. \& Pantǔček, R. (2020). Characterization of Staphylococcus intermedius group isolates associated with animals from antarctica and emended description of Staphylococcus delphini. Microorganisms 8: 204. https://doi.org/10.3390/microorganisms 8020204

Weber, P.C., Roland, P.S., Hannley, M., Friedman, R., Manolidis, S., Matz, G., Owens, F., Rybak, L. \& Stewart, M.G. (2004). The development of antibiotic resistant organisms with the use of ototopical medications. Otolaryngology - Head and Neck Surgery 130: S89-S94. https://doi.org/10.1016/j.otohns. 2003.12.009

Wijesinghe, G.K., Feiria, S.B., Maia, F.C., Oliveira, T.R., Joia, F., Barbosa, J.P., Boni, G.C. \& HÖfling, J.F. (2021). In-vitro antibacterial and antibiofilm activity of Cinnamomum verum leaf oil against Pseudomonas aeruginosa, Staphylococcus aureus and Klebsiella pneumoniae. Anais da Academia Brasileira de Ciências 93: e20201507. https:// doi.org/10.1590/0001-3765202120201507

Woo, P.C., Ng, K.H., Lau, S.K., Yip, K-T., Fung, A.M., Leung, K-W., Tam, D.M., Que, T-L. \& Yuen, K-Y. (2003). Usefulness of the MicroSeq 500165 ribosomal DNA-based bacterial identification system for identification of clinically significant bacterial isolates with ambiguous biochemical profiles. Journal of Clinical Microbiology 41: 19962001. https://doi.org/10.1128/JCM.41.5.1996-2001.2003 